\title{
DÜBLIN
}

Technological University Dublin ARROW@TU Dublin

\section{Rebooting Irish Higher Education: Policy Challenges for Challenging Times}

\author{
Ellen Hazelkorn \\ Technological University Dublin, ellen.hazelkorn@tudublin.ie
}

Follow this and additional works at: https://arrow.tudublin.ie/csercon

Part of the Higher Education Commons

\section{Recommended Citation \\ Hazelkorn, E. (2013) Rebooting Irish Higher Education: Policy Challenges for Challenging Times. Conference paper.}

This Conference Paper is brought to you for free and open access by the Centre for Social and Educational Research at ARROW@TU Dublin. It has been accepted for inclusion in Conference Papers by an authorized administrator of ARROW@TU Dublin. For more information, please contact arrow.admin@tudublin.ie, aisling.coyne@tudublin.ie,gerard.connolly@tudublin.ie.

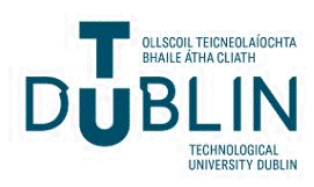




\title{
DRAFT
}

Rebooting Irish Higher Education: Policy Challenges for Challenging Times

\author{
Professor Ellen Hazelkorn \\ Higher Education Policy Research Unit (HEPRU) \\ Dublin Institute of Technology \\ 143 Rathmines Road, Dublin, Ireland \\ Tel. 00353872472112 \\ Email.Ellen.hazelkorn@dit.ie
}




\begin{abstract}
The 2008 global financial crisis (GFC) has cast a long shadow over Ireland and Irish higher education. In 2009, the IMF (2009) said Ireland was experiencing an "unprecedented economic correction...that exceeds that being faced currently by any other advanced economy", while Ireland's National Economic and Social Development Office (NESC 2009) said Ireland was beset by five different crises: a banking crisis, a fiscal crisis, an economic crisis, a social crisis and a reputational crisis. These circumstances provide the best explanation for the policy choices now confronting the government and higher education as they struggle to sustain the publicly-funded mass higher education and university-based research system, and reposition the country as a globally competitive knowledge society attractive to mobile capital and skilled labour. Whatever the outcome, it is unlikely that public funding for higher education will ever return to the levels enjoyed during the previous "golden age".

This paper examines the background and policy challenges confronting the government and higher education. After providing an overview of the economic and policy context, the chapter summarises four key policy challenges: i) creating a coherent higher education "system"; ii) sustainability; iii) research excellence; and iv) quality and performance. The conclusion discusses the challenges in terms of policy-trade offs and considers the implications.
\end{abstract}

Keywords: Ireland, higher education, economic recession, sustainability, system restructuring

\title{
Context
}

The arrival of the EU/ECB/IMF ${ }^{1}$ troika to bail-out the Irish state with over $€ 80 \mathrm{bn}$ has both transfixed and transformed the country over the past five years. Previously giddy with its new-found national and personal wealth, Ireland had been dubbed the "Celtic tiger", signifying its historic and rapid transformation from a country dependent on agriculture and traditional manufacturing to one based on hi-tech and internationally traded services effectively defying arguments about dependency theory (Gunder Frank 1989). By 2012, the latter accounted for $67 \%$ GDP, while industry was $31 \%$ and agriculture just $2 \%$. The reason for Ireland's success included a combination of

EU membership and access to the Single Market; Ireland's low corporation tax rate and a large multinational presence; a high proportion of the population of working age; increased participation in the labour market especially by females; a reversal of the trend of emigration toward immigration; sustained investment in education and training; co-ordinated social partnership agreements and a more stable public finance position (ESRI n.d.)

During these years, tax revenue surged, enabling the government to expand expenditure on services and national infrastructure projects. Between 2000 and 2007, the annual average growth in real GDP and real $\mathrm{GNP}^{2}$ was $5.7 \%$ and $5.0 \%$, respectively; in 2006, the government recorded a surplus of 3\% GDP (ESRI 2013).

After decades of relatively high unemployment and emigration, with a population hovering under $4 \mathrm{~m}$, the early $21^{\text {st }}$ century represented a tremendous turn-about. Ireland had the fastest growing population in the EU, rising by $17 \%$ between 2002 and 2011 to $4.6 \mathrm{~m}$ with estimates that by 2060 the population could reach $6.7 \mathrm{~m}$ (RTE 2007; O'Brien 2008). The labour force 
grew from $1.2 \mathrm{~m}$ in 1990 to $2.1 \mathrm{~m}$ in 2007 , equivalent to a $75 \%$ increase. At the same time unemployment rates fell to a historic low, averaging $4.5 \%$ in 2007.

However, by 2009, all had changed utterly. In addition to the direct impact of the GFC, Ireland's downturn was attributed to an overdependence on the domestic housing market, and a steep deceleration in export growth exposing structural problems of trade-dependency. Between 2008 and 2011 real GDP declined by 5.4\%, while real GNP declined by $10.1 \%$. At the same time, the government was forced to spend almost €73bn to bail-out the banks, causing public debt to rise. As domestic investment fell, unemployment rose sharply, reaching $14.7 \%$ in 2012 , with a knock-on effect on tax receipts.

In response to the deteriorating situation, the Irish government adopted a deflationary strategy aimed at increasing Ireland's competitiveness:

We need to ask ourselves if we can price ourselves back into the market rapidly ... If we do we will see a very robust recovery by 2012, unemployment will come down gradually from 2011 onwards, and we might get back to full employment by 2015 (Lynch and Slattery 2009).

The 2009 budget marked the beginning of a series of actions which saw reductions in overall government spending including public sector staff numbers, salaries and pensions of almost $€ 11.5 \mathrm{bn}$, and increased taxation (GoI 2012, 3).

Higher education has not been immune from these developments; a beneficiary of the boom, it has become a victim of the crisis. Until recently, policy was dominated by questions of massification and access, getting more people well-educated; today, the emphasis is on quality and sustainability in the context of accelerating global competitiveness and the reality of the post-2008 Irish economy. Ireland faces the dual challenge of meeting extensive socioeconomic and demographic demands on/for higher education at a time of decreasing public budgets and public support for publicly-funded institutions. Even when the economy returns to growth, it is unlikely that funding will return to levels enjoyed during the previous "golden age". At the same time, Ireland is struggling to reposition itself as an attractive venue for global capital and skilled labour and to sustain its publicly-funded mass higher education and university-based research system. It has chosen to preserve its social-democratic values, emphasizing the importance of the overall "system" rather than promoting individual institutional performance. While competitor countries, across Europe and internationally, are confronting roughly similar circumstances, many are also investing significantly in both higher education and research. Thus, Ireland's circumstances pose significant policy challenges and trade-offs.

This paper examines the background and policy challenges confronting the government and higher education. After providing a summary of Irish higher education development, the chapter reviews four key policy challenges: i) creating a coherent higher education "system"; ii) sustainability; iii) research excellence; and iv) quality and performance. The conclusion discusses the challenges in terms of policy-trade offs and considers the likely options.

\section{Transformation of Irish Higher Education}

\section{i) Expansion of Higher Education}

At the start of the 20th century, 3,200 students were enrolled at six universities on the island of Ireland (Coolahan 1981), demonstrating a strong connection between social status and participation. Today, Ireland has a binary system albeit it is more complex and varied than the term usually suggests (Skilbeck 2003). There are thirty-nine higher education institutions 
(HEI) - principally seven universities and fourteen institutes of technology (IoT) - in receipt of over $€ 1 \mathrm{bn}$ annually in core grant and grant in lieu of fees, serving around 170,000 students and estimated to rise to over 250,000 by 2020 (HEA, 2013a). Due to a combination of planned investment and targeted policies, national participation rates have increased from $20 \%$ in 1980 to $69 \%$ today. Sixty percent of total students are enrolled in universities and $40 \%$ in IoTs, while post-graduate enrolment is increasing in the IoTs, $84 \%$ are enrolled in the Universities (HEA 2012a). There is an uncoordinated and unrecognised further education (FE) sector and a small number of for-profit institutions.

Over the decades, expansion has been underpinned by strong societal appreciation of the benefits of educational attainment for personal and societal advantage, which underwrote the "public contract" in favour of significant expansion in national funding. A critical component was the link between the introduction of free secondary education in the mid-1960s and economic growth, which, in turn drove demand for higher education. Investment in Education (1965), initiated in co-operation with the OECD, was the first major policy document published on education. Labour shortages brought about by rapid economic growth and international competitiveness underpinned the importance of higher education (Harpur 2010, 77). With access to EU funds, policy shifted away from dependency on the public sector towards liberalization, privatisation and diversification. There was universal endorsement of strategic targeting and marketing of Ireland as an "information gateway", an Englishspeaking beachhead between the USA and Europe.

However, higher education remained largely disconnected from other policy considerations until first, the benefits of the "information society" began to dominate policy discourse across Europe in the early 1990s (Bangemann 1994), and second, following the Lisbon Strategy in 2000 "to make the Union the most competitive and dynamic knowledge-based economy in the world by 2010" (EU 2000), European policy moved decidedly to embrace the "knowledge economy". Irish policy followed suit (Harpur 2010, 78); the National Development Plan (GoI 2006, 17) pledged to enhance enterprise development, and "improve economic performance, competitiveness...generate new enterprise "winners" from the indigenous sector [and] attract high added value foreign direct investment". This placed education and university-based research at the centre of policymaking in a dramatic new way.

The transformation of Irish higher education was visible almost everywhere. Universities and IoT campuses expanded in all dimensions; a massive building programme led to new student, sport and cultural facilities, specialised teaching spaces, and most notably research institutes with internationally competitive laboratories. Other observable signs included the establishment of the National Qualification Authority of Ireland (2001) and two sectorspecific quality assurance agencies; the Higher Education Authority (HEA), initially and primarily a funding agency for the universities, adopted a broader mandate for education and research for all HEIs, and advocate and driver of change and "modernisation". Research activity, productivity and visibility increased, but despite increases in the rate of investment in higher education and $\mathrm{R} \& \mathrm{D}$, Ireland continued to remain well below both the EU and OECD average (Ó Riain 2004, 33).

\section{ii) Responding to the Crisis}

As the economic crisis hit harder, higher education has experienced significant reductions; overall exchequer funding for recurrent purposes to publicly-funded HEIs, which is $95 \%$ of institutions which students attend, has been reduced by c.25\% between 2008 and 2012. The reduction was partially offset by increases in the student contribution and reductions in employment numbers via the Employment Control Framework and two national agreements on public sector employment and salaries, bringing the overall reduction down by $10 \%-12 \%$ 
(HEA, 2012b). Figure 2 illustrates the decline per institution. Research funding programmes were initially restricted (Duke 2009) or subsequently revised in line with new priorities (see discussion below).

Figure 1 Decline in Block Grant Funding: 2008-2012

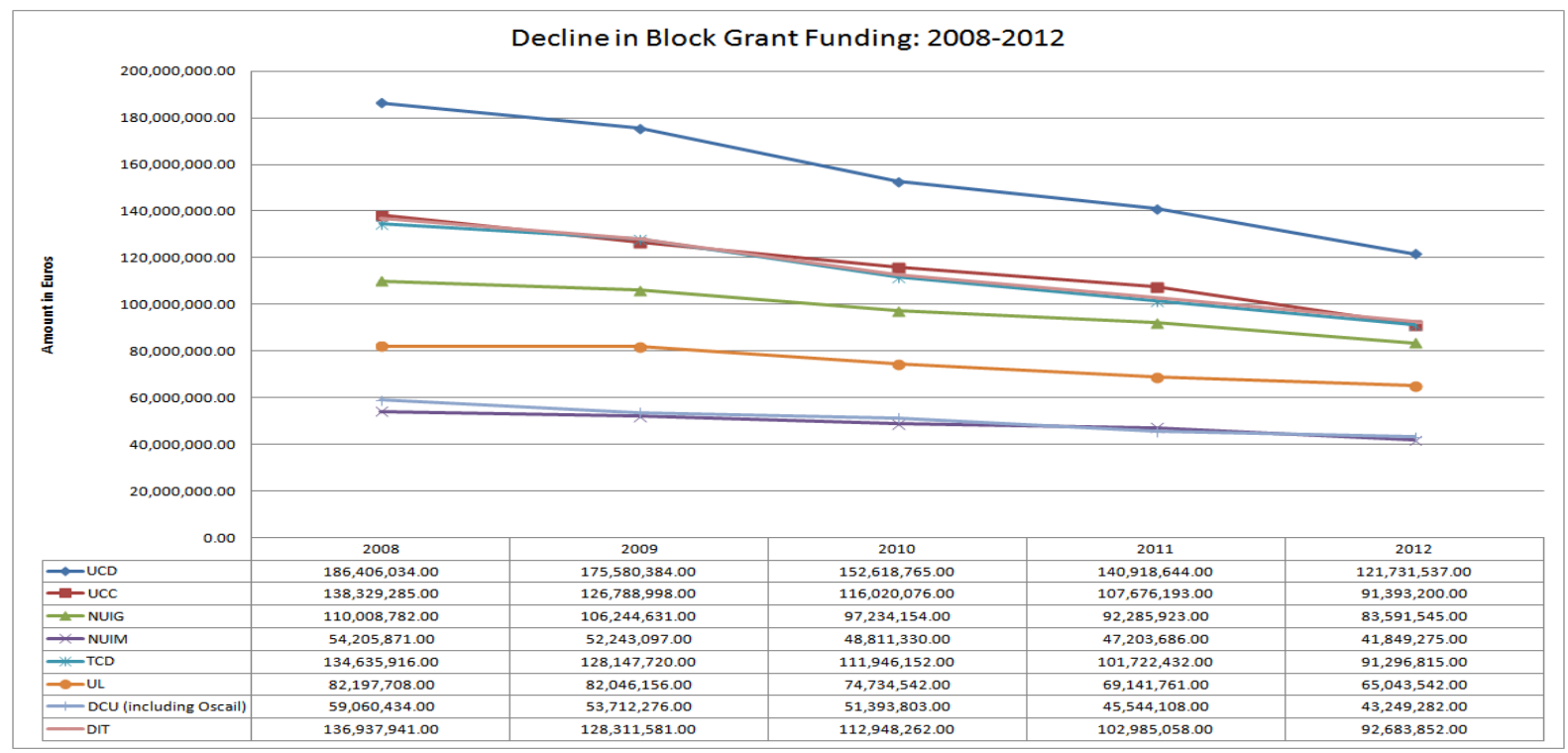

Source:

http://oireachtasdebates.oireachtas.ie/debates\%20authoring/DebatesWebPack.nsf/takes/dail20 $\underline{12111300067 \# \mathrm{~N} 47}$

The government's policy response was signalled through several major reports and initiatives briefly described below:

- Building Ireland's Smart Economy (2008) aimed to position Ireland as a knowledgeintensive economy with a "thriving enterprise sector, high-quality employment, secure energy supplies, an attractive environment, and first-class infrastructure." It strongly endorsed heavy investment in R\&D. Reform and restructuring of higher education was also a central feature (GoI 2008, 3).

- Special Group on Public Service Numbers and Expenditure Programmes (2009) examined expenditure across all government departments, proposing $€ 10.2 \mathrm{~m}$ savings from higher education. It questioned spending on research and the emphasis on training $\mathrm{PhDs}$, and proposed amalgamating all research funding into a single agency. It also criticised academic/non-academic contracts (DoF 2009).

- Innovation Taskforce (2010) proposed that Ireland should focus on being a "clever copycat" rather than developing its own R\&D capacity; in other words, Ireland should do the "D" in R\&D (Innovation Task Force 2010, 15).

- National Strategy for Higher Education to 2030 (DoEs 2011) recommended rationalisation and merger to create efficiencies and increase mission diversity, proposing that HEIs should be subjected to greater oversight through a strategic dialogue process and institutional contract. It also suggested a graduate tax or an income contingent loan system as an alternative to a no-tuition fee policy in order to inject needed funds into the system. 
- Towards a Future Higher Education Landscape (HEA 2012c) set guiding principles and objectives for a "co-ordinated system of higher education" with an emphasis on mission distinctiveness. The future system will be characterized by differentiation based on qualifications level, discipline specialization, programme orientation, regional engagement, student profile, mode of provision, and research intensity and specialization. In 2013, the Minister for Education and Skills approved the Report on System Reconfiguration, Inter-Institutional Collaboration and System Governance in Irish Higher Education (HEA 2013b).

- Research Prioritisation Exercise (RPE) (Forfás 2011) identified fourteen priority areas plus six platform sciences and technology for targeted funding. With an emphasis is on (industrial) relevance, each field was assessed against four high-level criteria: association with large global markets in which Irish-based enterprise does/can realistically compete; public investment in $\mathrm{R} \& \mathrm{D}$ is necessary and can complement private sector research; Ireland has objectively measured strengths; and the field represents a national or global challenge to which Ireland should respond.

- Quality and Qualifications Ireland (2012) created a single quality assurance authority and regulator for all further education (FE) and HE (public and for-profit sector) institutions.

While there are differences in emphasis between these different reports and initiatives, in their totality they represent a significant move towards greater government steerage of a coordinated higher education and research system which is in greater alignment with the needs of the economy. The intention is to increase accountability to deliver outputs in line with national priorities, in terms of curriculum and graduates, and new knowledge, products and services. It also reflects the continuing shift from a traditional "primacy of the humanities and classical studies" towards science and technology (Walsh 2011, 366). While there are specific Irish factors, this follows the trend across Europe (Ferlie et al 2008). The next section looks individually at the key challenges for higher education that emerge.

\section{Issues and Challenges}

Arising from the changed economic circumstances and the policy decisions, this section discusses the challenges for higher education - for its competitiveness, quality, attractiveness and sustainability.

Ireland has achieved a remarkable expansion of higher education opportunities over recent decades... Our younger workforce is among the most educated in the OECD but the educational attainment levels of older workers are poor by international standards. Our output of qualifications at NFQ Levels $6 \& 7^{3}$ is a strength, but we are average in terms of the overall attainment at Levels 8-10 and below average in terms of the output of PhDs.... However, since the collapse of Irish public finances, the perception of the quality of Irish higher education internationally has suffered (HEA 2012c, 2).

Even if the economy had not collapsed, these issues would still have required attention; indeed, it is arguable that Ireland has been late tackling many of these issues.

i) Creating a coherent higher education "system"

A strategic review of higher education was conducted between 2009 and 2011, with the aim of going beyond the 2004 OECD Review of Higher Education in Ireland. Originally conceived in 2008, by the time it was announced in February 2009, the economic situation had become the dominant preoccupation. The team was tasked with assessing higher 
education's fitness-for-purpose, developing a vision and national policy objectives, and identifying "focused targets" for the following five years, "having particular regard to the difficult budgetary and economic climate that is in prospect in the medium term" (HEA 2009). The National Strategy for Irish Higher Education to 2030 (henceforth: the Report) was released in January 2011 and endorsed by the in-coming government as "not perfect" but "sufficient" (Quinn 2011).

The Report was wide ranging, however, its most notable recommendation was the emphasis it placed on the performance of the system as-a-whole. Greater accountability would be achieved by ensuring strategic and mission alignment to agreed targets (DoES 2011). It also endorsed the idea that all HEIs should be involved across the three pillars of teaching, research and engagement, albeit the balance would depend upon institutional mission. Mergers were strongly favoured, particularly within the IoT sector, with the opportunity for a new kind of university - a technological university - to be created from among the larger, internationally competitive IoTs. Finally, the Report proposed the formation of "regional clusters" as lose alliances of HEIs to help drive greater system integration, joint programming, articulation across programmes and institutions, improved student experience through enhanced facilities, and greater efficiency through rationalization of resources including back-office functions.

These matters divided the original review team between traditionalists and modernizers; while there was a view that Ireland had too many HEIs relative to population, there was little support for concentrating resources in a few "world-class" universities (Flynn 2010; von Prondzynski 2009; McConnell 2009). However, there was disagreement between those favouring retention of the traditional binary system versus those favouring greater mission diversity through supporting excellence where it occurs. In the end, the latter vision won out - but not before inclusion of a dissenting footnote.

The implementation phase is now in progress. The HEA has developed a package of strategic measures intended to create a more coherent and cohesive system of institutions working together rather than individual institutions pursuing their own agenda. The challenge, however, is balancing the over-arching requirements of the "system" with those of institutional autonomy, often portrayed as academic freedom. The universities, which have traditionally enjoyed greater autonomy than IoTs, argue that the new policy environment and associated political scrutiny is intrusive. Indeed, the Minister has threatened new legislation forcing university compliance with government decisions (RTE 2012). Nonetheless, there is probably little public sympathy with the plight of higher education given the level of "pain" endured by other sectors of society since 2008 .

Higher education is undergoing significant restructuring through enhanced collaboration and merger, at a level not seen outside the health sector - with which analogies can be made. The emphasis is on over-coming fragmentation and duplication, while enhancing critical mass. There is some discussion about hubs-and-spokes type model aka the Wisconsin system model, especially with respect to creating better pathways from associate degree Level 6 to bachelor level 8 qualifications, and for doctoral programmes. There have also been formalised conversations between the secondary and higher education sectors with the intention of looking at transition and preparation. Thus far, the FE sector - or what could be classified as such - has been absent from these discussions, partially because it is undergoing its own restructuring, but this is likely to emerge as a critical issue in the near-future. 
Sustainability is the biggest challenge facing Irish higher education, reflecting the co-relation between funding, quality and participation. Because people are considered Ireland's natural resource, widening participation and high levels of participation have been critical. Research indicates Ireland will have a growing demand for skilled labour over the next 20 years: a minimum $48 \%$ of the labour force having qualifications at BA, MA, PhD level, $45 \%$ at secondary level and 7\% at primary (Forfas 1995). At the same time, demand analysis shows the number of undergraduate higher education entrants is expected to grow by $24 \%$ reflecting Ireland's comparatively high fertility rate (CSO 2012, 10.). While it is difficult to precisely align supply and demand, any reduction in the level of provision or changes in demographic trends, could nonetheless lead to graduate shortages (McGuinness et al 2012,8).

Yet, at the same time, overall funding (core grant, student contribution, etc.) per student has decreased by almost $20 \%$ from 2007 to $€ 8,000$ in $2010 / 11$. This reduction has been offset to some extent by increases in the student contribution and by the impact of salary reductions. However, over the same period, full-time student numbers have increased by c.11\%. Comparative data shows per student funding in Ireland is between $19 \%$ and $29 \%$ lower than in England (HEA 2011, 5). While typical output data, such as student progression, graduate completion, employability, research activity, and student and employer satisfaction continue to show good returns, the staff-student ratio is rising, and the number and position of Irish HEIs in global rankings have fallen (see discussion below). The additional cost required to meet the $30 \%$ surge in student numbers could, it is estimated, result in a short-fall of almost $€ 241 \mathrm{~m}$ by $2026 / 07$.

The strategy being adopted, therefore, is to try to determine the quantum of funding required and then identify a range of actions which, when combined, can provide the best relationship between resources and outcomes sought. Actions being pursued include programme rationalisation, shared services and outsourcing, changes to the academic year, changes to academic contracts, rebalancing provision between $\mathrm{FE}$ and $\mathrm{HE}$, and changes to the institutional funding model. The latter will see greater alignment between funding and performance.

The big political hot-potato is tuition fees, otherwise referred to as the student contribution. Undergraduate fees were abolished in 1997 as a means of widening participation but also in recognition that the revenue system, at that time, could not adequately redress inequities in the grant system. Thus, children of farmers and other self-employed could more easily avail of financial support than children of public or private sector workers. Simultaneous to the "free fees" regime, an IR£150 (c.€190.50) student registration fee was introduced to cover registration, exams and student activities. It has increased ever-since, and is set to rise to $€ 3,000$ by 2015 . There is a student grant system but no loan programme. In contrast, all postgraduate students pay a tuition fee.

Politically, the re-introduction of tuition fees was always going to be highly contentious because the main beneficiaries were the vocal middle class. While their abolition did not bring electoral benefit, any suggestion of their reintroduction is likely to provoke a backlash which neither government party can afford. Nonetheless, the large public deficit dictates that position is no longer tenable. Various cost-sharing options are under consideration, including introducing tuition fees or, at a minimum, a means-tested or higher student contribution from families who can afford to pay, variegated fees for different programmes or allowing institutions to set a market-based fee; restricting student numbers nationally or per HEI; and expanding the role of private providers - but all carry policy and political risks. During 2009, the then Minister for Education and Science was on the verge of announcing a scheme based 
upon the Australian HECs system but baulked at the last moment (Kearns 2009, 11; HEA. 2009b). However, none of these options will make up the short-fall or bridge the funding gap as the government is likely to simply reduce the core grant accordingly.

\section{iii) Research Excellence}

Prior to 2000, Ireland had no national research policy, investment strategy or noteworthy international reputation in scientific research (Hazelkorn et al 2013). However, since 1997, almost $€ 3$ bn has been invested to make Ireland "internationally renowned for the excellence of its research...and using new knowledge for economic and social progress, within an innovation driven culture" (NDP 2007) (see Figure 2). Emphasis has been placed on increasing the number of research teams led by internationally competitive principal investigators; upgrading existing infrastructure and developing new facilities to support research; enhancing postgraduate skills through a graduate schools mechanism; developing sustainable career paths for researchers including mobility opportunities; and doubling the number of $\mathrm{PhD}$ graduates by 2013. Notable actions included the Programme for Research in Third Level Institutions (PRTLI) (1998), establishment of Science Foundation Ireland (SFI) (2000) modelled on the US National Science Foundation, and the Strategic Innovation Fund (SIF) (2004). While PRTLI supported world-class research in the humanities, science, technology and the social science, including business and law, SFI supported research in biotechnology, information and communications technology, and sustainable energy and energy-efficient technologies. Together these initiatives have ensured Ireland has both broad and deep based research capacity and capability.

Figure 2 Total R\&D Expenditure in the Irish Higher Education Sector as a \% of GDP, 19952011

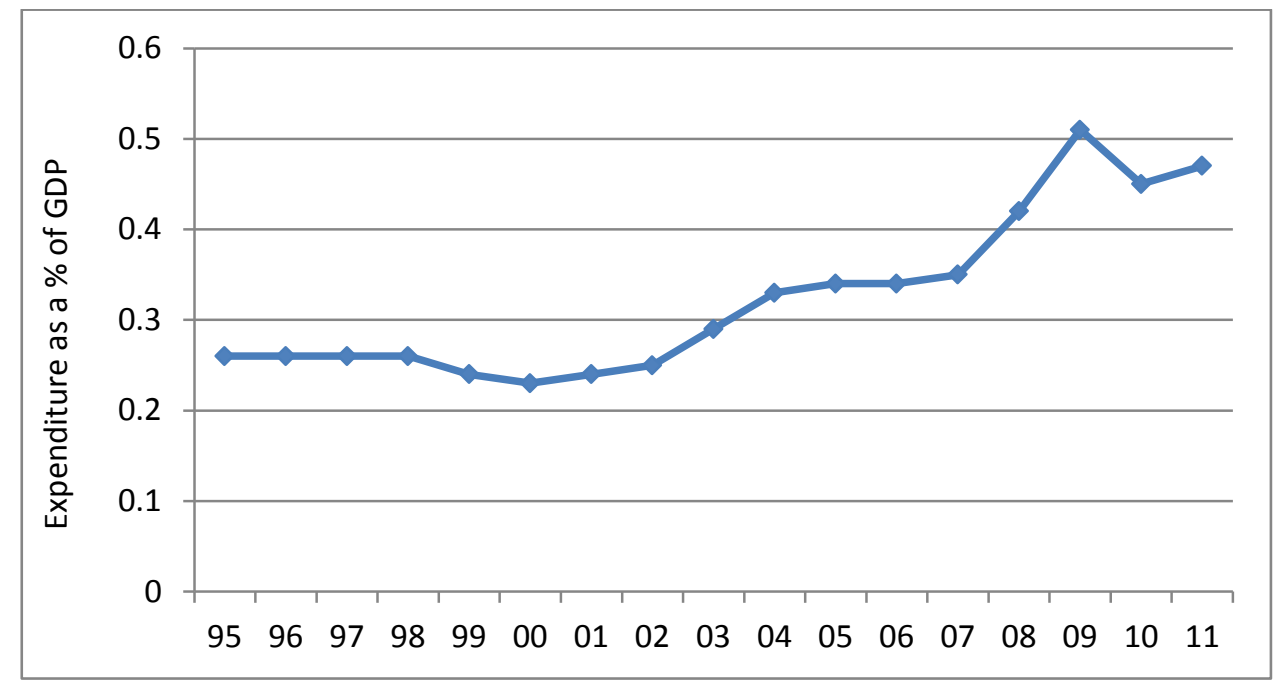

Source: Eurostat

The economic crisis, however, changed both the quantum and approach to research and its funding. While overall government funding has remained relatively constant at about $0.5 \%$ GDP since 2008, real funding has fallen by c.16\% between 2008 and 2012 (Forfas 2013, 4) albeit compared with the decline in funding to the HEIs themselves, research has done relatively well reflecting the government's overall strategic aim of positioning Ireland as a knowledge economy in ICT, energy, bio-technology and pharma, and more recently agrifood. When compared with European neighbours (the EU 27 average was 0.64\%GDP in 2002 and $0.65 \%$ GDP in 2011), Ireland's investment intensity remains weak, even when using 
the more favourable GNP levels: GNP: $0.47 \%$ (2002) - 0.63\% (2011) vs. GDP: 0.39\% (2002) - $0.50 \%$ (2011) (Forfas 2013, 15).

Simultaneously, focus of discussion shifted markedly towards questioning the value of research, the type of research being undertaken and the immediacy of the public benefit. There are several aspects to this policy change:

- Reallocation of the major research budget to the Department of Jobs, Enterprise and Innovation (DJEI) and away from the Department of Education and Skills (DoES) and the Higher Education Authority;

- Expansion of the role and budget for Science Foundation Ireland, followed by the appointment of its Director as the National Science Policy Advisor, confirming SFI as the dominant research leader;

- Research Prioritisation Exercise (RPE) re-aligned research with industrial sectors accounting for approximately $80 \%$ of national competitive funding;

- Assessment criteria considers research relevance foremost, before excellence, with attention to short-term outputs, impacts and benefits for the Irish economy;

- Assignment of "research for knowledge" and "research for policy" to the new Irish Research Council, which replaced the two discipline-specific councils for the humanities and social sciences, and for science, engineering and technology.

While the HEA has been given authority to co-ordinate departmental actions, its role in helping frame or drive research policy has been marginalised.

Arguably because of the decade of investment, and in contrast to Ireland's otherwise declining performance in global rankings (see below), research performance has been climbing. The Thompson Reuters' National Citation Report (Ireland), University Science Indicators (ISI), and global comparisons data all indicate an improvement in Irish universities' research performance. A recent report by Nature identified Ireland as one of the countries to watch: "Despite its dire economic circumstances, Ireland is emerging as a rising star - jumping from 30th to 20th in the NPI between 2008 and 2012" (Swinbanks 2013, 1; see also 25-26; EU, 2012; Forfás 2009). The difficulty with all these indicators is that there is lag factor, and the challenge is ensuring that changes improve the situation rather than undermine it.

The key difference in the new approach lies in the (re)orientation of research, and the more directive involvement of government in shaping research priorities and funding criteria. The RPE marked the end of the strategy to build a broad base of expertise in favour of a "more top-down, targeted approach". However, by focusing narrowly on research applied to key industrial sectors there are concerns about unintended implications for the broader ecosystem, including for undergraduate teaching and learning, the academic profession, and recruitment and career progression in HEIs institutions. Overconcentration or focus on some disciplines or fields of science at the expense of others (for example, the arts and humanities) may produce perverse incentives with unintended knock-on effects for the other disciplines and institutions or regions, and hence the intellectual base and attractiveness of society-as-awhole. This represents a significant shift from higher education as human capital development underpinning civil society to being an arm of economic policy. Some of these developments will positively encourage quality specialisation rather than sheer comprehensiveness, but they could equally affect the breadth and balance across disciplinary provision. 


\section{iv) Quality and Performance}

Over the decades, there has been a noticeable shift from direct government management and micro-administration of HEIs towards greater institutional autonomy; however, recent years have seen the end of the "era of laissez faire" (Boland 2009). Internationally, there is also a growing trend which sees quality assurance increasingly government-driven rather than institution-led. Regulation and directed governance through performance monitoring, funding, rankings and ratings, etc. are becoming more commonplace (Hazelkorn, 2013b). These trends are true for Ireland.

A new agency, Quality and Qualifications Ireland (QQI), is bringing together four different agencies, each of which had a sub-sectoral perspective; QQI will drive quality enhancement but also regulate the emerging for-profit sector. The latter is a new force, not just in terms of meeting rising demand as exemplified by demographic figures but as part of an un-stated "policy" that sees the for-profit sector as an alternative or partner to the publicly-funded system. There is already some evidence; the government's initiative, SpringBoard, for reskilling/re-training unemployed people has been opened up to the for-profit sector for the first time. However, there is no data about the shape or size of the sector, or anything about student outcomes or progression. This raises fundamental quality concerns that will need to be addressed promptly.

But most quality concerns arise over limitations on the state's capacity to fund mass public higher education at a time of accelerating global competitiveness and investment from peer countries.

The critical importance of these rankings should not be doubted. The perceived quality of the higher education system is a key factor in helping to attract inward investment. The rankings can also help Ireland to attract more international students, a lucrative business opportunity...'(The Irish Times 2009, 15).

While rankings are not a measure of quality, they do provide some indication of standing internationally. Undoubtedly the decline in Ireland's economic standing since 2008 has had a negative impact on national reputation, with knock-on consequences for higher education and their ranking (see Table 1). In the 2010-2011 THE World University Rankings, two Irish HEIs were ranked in the top 100, with Trinity College Dublin (TCD) ranked 76 and University College Dublin (UCD) ranked 94, albeit this obscures the fact that TCD had ranked 49 according to THE/QS in 2008. By 2012-2013 TCD was ranked 110 and UCD 187, leaving no Irish university in the top 100. Performance in the QS ranking has fared similarly; by 2013, only TCD remained within the top 100 and 3 had fallen below 500. In the 2012 Academic Ranking of World Universities (ARWU), only TCD was within the top 300, with UCD and University College Cork (UCC) securing places within the top 400. This negative trend is further reflected in the fact that no Irish university features in the THE World Reputation Rankings, however, several Irish universities do feature in the THE ranking of universities less than 50 years' old, in which reduced weighting is given to the academic reputation survey. In 2012, three universities were ranked: National University of Ireland, Maynooth (NUIM) at 64, Dublin City University (DCU) at 86, and the University of Limerick (UL) at 97. 
Table 1 Ranking of Irish Higher Education in Global Rankings, 2008-2013

\begin{tabular}{|c|c|c|c|c|c|c|}
\hline & \multicolumn{2}{|c|}{2008} & \multicolumn{2}{|c|}{2010} & \multicolumn{2}{|c|}{2013} \\
\hline & $\begin{array}{l}\text { Top } \\
100\end{array}$ & $\begin{array}{c}\text { Top } \\
400+*\end{array}$ & Top 100 & $\begin{array}{c}\text { Top } \\
400+*\end{array}$ & Top 100 & $\begin{array}{c}\text { Top } \\
400+^{*}\end{array}$ \\
\hline ARWU & 0 & 3 & 0 & 3 & 0 & 3 \\
\hline THE World Rankings & & & 2 & 3 & tbc** $*$ & tbc** \\
\hline $\begin{array}{l}\text { QS Top University } \\
\text { Rankings }\end{array}$ & 1 & 6 & 1 & 6 & 1 & 6 \\
\hline
\end{tabular}

Notes:

*While THE ranks to top 400, ARWU ranks to the top 500 and QS to $601+$.

**QS 2013-2014 ranking is due 10/09/2013 and THE due on 02/10/2013.

Partially in response to these trends and partially ideologically, the government has focused attention on the capacity of the system overall, saying that given restrictions on resources "we need to maintain a clear focus on system performance overall rather than a narrower focus on individual institutional performance" (Quinn 2012). Accordingly, the government, through the HEA, is in the process of implementing the strategic dialogue process. The National Strategy for Higher Education to 2030 (2011, 91) described this as a way to align "the strategies of individual institutions with national priorities and agreeing KPIs against which institutional performance will be measured and funding decided". These service-level agreements or compacts are a means by which the HEA will monitor performance, and establish quality markers. Rather than being seen as intrusive or directive, it will supervise institutional strategic plans so as to maintain mission diversity. In this respect, it is following a path (being) developed in Australia, Denmark, Norway, the Netherlands and Hong Kong. As part of the process, the government has produced A Higher Education System Performance Framework for 2014-2016; the document identifies the over-arching national and institutional objectives (see Box 1) (Quinn 2013).

\section{Box 1 Key system objectives for 2014-16:}

1. To meet Ireland's human capital needs across the spectrum of skills by engaged institutions through a diverse mix of provision across the system and through both core funding and specifically targeted initiatives;

2. To promote access for disadvantaged groups and to put in place coherent pathways from second level education, from further education and other non-traditional entry routes;

3. To promote excellence in teaching and learning to underpin a high quality student experience;

4. To maintain an open and excellent public research system focused on the Government's priority areas and the achievement of other societal objectives and to maximise research collaborations and knowledge exchange between and among public and private sector research actors;

5. To ensure that Ireland's higher education institutions will be globally competitive and internationally oriented, and Ireland will be a world-class centre of international education;

6. To reform practices and restructure the system for quality and diversity;

7. To increase accountability of autonomous institutions for public funding and against national priorities. 
The new approach will certainly test all concerned. The HEIs will need to have the strategic and leadership capacity to not only identify the most appropriate benchmarks but also achieve them, as missing targets will affect budgets. The HEA was historically the administrative unit responsible for funding allocations to the universities only; as of 2006, it was given responsibility for the IoTs. This new direction, granted under the national strategy, requires a deeper and more sophisticated understanding of how HEIs, as dynamic and not static entities, work in reality rather than just in theory. Great care will need to be taken to ensure traditional preconceptions or biases are not replicated. To help, the HEA has recruited a panel of external experts but this process previously led to a tense political situation, when the external panel proposed, as an alternative, a unitary system but ran quickly to ground with more conventional departmental thinking. So care will need to be taken in this respect also.

Having said all this, the key challenge for the strategic dialogue process is what happens if the targets are not met? Some targets are set against the system, to be overseen by the HEA, and some set at the institutional level. Getting the balance right will be tricky, especially as some of the latter are contingent upon performance of the former; this is part of the challenge associated with the regional clusters. The concept is loosely based upon triple helix concepts but they don't actually correlate with any popular understanding of regions in Ireland. The HEA has set them objectives, but these are principally sui generis to higher education without any socio-economic component. The challenge will be getting HEIs, notoriously competitive, to be collaborative; the trigger is funding.

\section{Conclusion: Policy-Trade Offs and Implications}

The suddenness and severity of the economic crisis has thrown assumptions into question. At a time of mounting global and domestic pressures and declining budgets, policy considerations involve a series of trade-offs between good and least bad options (Hazelkorn, 2013a). Policy trade-offs involve balancing different options or policy goals (Jongbloed 2004), which become especially acute "because different stakeholders interpret evidence differently: stakeholders may assign different weights to policy goals and may even define the same goals differently" (Mah 2008, 192). In Ireland, this involves adopting new rules and expectations.

The focus on creating a system of coherent institutions has required once warring HEIs to begin to work together under a framework not entirely to their likely. It certainly sees more government involvement if not interference, challenging conceptions of institutional autonomy. Mergers and acquisitions, long considered a feature of the corporate world, is now part-and-parcel of Irish higher education life. The universities lost and won their longstanding battle to prevent any additional "universities" being created; new technological universities are possible but only if they meet certain criteria. Nonetheless, the universities have already factored at least one into their future calculations and have also moved quickly to eye-up the opportunities of incorporating smaller institutions.

Beneath the surface, there is deep concern over sustainability of the higher education and research system; this is shared across the sector, and by the HEA and government, albeit everyone acknowledges "we are where we are" and chances of a new "golden era" are not realistic. Ideological commitments to free mass public higher education are being cast adrift as discussions turn to alternatives; this inevitably means variations of cost-sharing, increased productivity, lengthening the academic year including the introduction of a third (summer) semester, etc. Politically all these actions are difficult, not least because the government promised it would not introduce tuition fees upon coming into office. Changes in academic 
work involve union negotiations. There has been some gain with respect to salary reductions and productivity within existing contracts but anything beyond that will be difficult to achieve in the short-term.

Aligning research to industrial sectors, which is essentially what the prioritisation exercise achieved, has been controversial. The government has sought to reassure the academy about the importance of "fundamental" research, and the arts and humanities, but the distribution of the funding envelope tells a different story. The government is also beginning to covet the research component of the core grant which is part of the HEA's allocation. Accordingly, a review of the Irish innovation system, distinct from the previous reviews of the higher education and research priorities, is now being mooted. However, if the abovementioned results from Nature say anything, it is that improvement derives from solid investment and inter-dependence between higher education and research. There is, thus, some trepidation that a narrow focus on measurable impacts and benefits of techno-science could lead to changes being made in one part of the eco-system independently of the other, leading to adverse unintended consequences for other disciplines and institutions or regions, and hence the intellectual base and attractiveness of society-as-a-whole.

However all is not gloom. If Ireland was a test-bed for rapid economic development, it is quickly becoming a test-bed for new thinking about higher education. There are a noticeable number of other jurisdictions also beginning to focus on the quality of the system over-all rather than individual institutional performance (see Lane and Johnstone, 2013). An important dialogue is now occurring across the sector; HEIs, whose personnel rarely met despite the countries small size, are now actively engaged in conversations about research, teaching programmes, access initiatives, shared resources including libraries, etc. There are also signs of a public dialogue. This all suggests that in some ways Ireland might be leading rather than simply surviving.

\section{References}

Anon. 2012. Quinn says no to "narrow focus" on university performance. the journal.ie. http://www.thejournal.ie/quinn-says-no-to-narrow-focus-on-university-performance-430836Apr2012/

Bangemann, M. 1994. Report on Europe and the Global Information Society:

Recommendations of the High-level Group on the Information Society to the Corfu European Council. Bulletin of the European Union, 2, no. 94. http://www.cyberrights.org/documents/bangemann.htm

Boland, T. 2009. Directed diversity - a strategy for Irish higher education system for the $21^{\text {st }}$ century. Presentation to Colloquium: World Class Universities or World Class Universities, Dublin: Dublin Institute of Technology.

Coolahan, J. 1981. Irish Education: Its History and Structure. Dublin: Institute of Public Administration.

CSO. 2012. Women and Men in Ireland 2011, Dublin: Central Statistics Office

DoES. 2011. National Strategy for Higher Education to 2030. Report of the Strategy Group.

Dublin: Department of Education and Skills. http://www.hea.ie/sites/default/files/national_strategy_for_higher_education_2030.pdf

DoF. 2009. Special Group on Public Service Numbers and Expenditure Programmes. Dublin: Department of Finance. $w w w$. finance.gov. ie/viewdoc. asp? DocID $=5861$. 
Duke, S. 2009. Disquiet Follows Irish Science Budget Cut and Policy Shift. Science Insider, http://news.sciencemag.org/scienceinsider/2009/12/disquiet-follow.html.

Editorial. 2009. University Rankings. The Irish Times. October 9.

ESRI. 2013. The Irish Economy. Dublin: Economic and Social Research Institute. http://www.esri.ie/irish_economy/.

ESRI. n.d. Irish Economy Overview. Dublin: Economic and Social Research Institute. http://www.donnerenviedentreprendre.com/documentation/IMG/pdf/_130_Irish_Economy_O verview.pdf.

EU. 2000. Lisbon European Council 23-24 March 2000. Presidency Conclusions. Brussels: European Commission. http://www.europarl.europa.eu/summits/lis1_en.htm.

EU. 2012. Innovation Union. http://ec.europa.eu/research/innovation-union/pdf/state-of-theunion/2012/innovation_union_progress_at_country_level_2013.pdf

Ferlie, E., Musselin, C. and Andresani, G. 2008. The steering of higher education systems: a public management perspective. Higher Education. 56, 325-348.

Flynn, S. 2010. Sutherland says number of universities must be cut. The Irish Times, January 23. http://www.irishtimes.com/newspaper/ireland/2010/0123/1224262926822.html.

Forfás. 1995. Science, Technology and Innovation Advisory Council Report. Dublin: Forfás. http://www.forfas.ie/media/forfas950327_science_technology_innovation.pdf.

Forfás. 2009b. Research strengths in Ireland: A bibliometric study of the public research base. Dublin: Forfás. http://www.forfas.ie/media/forfas091209 bibliometric_study.pdf

Forfás. 2012. Report of Research Prioritisation Steering Group. Dublin: Forfás. http://www.djei.ie/publications/science/2012/research_prioritisation.pdf

Forfás. 2013. State Investment in Research and Development, 2011-2012. Dublin: Forfás. http://www.forfas.ie/media/29082013-

State_Investment_in_Research_and_Development_20112012-Publication.pdf

GoI. 2006. National Development Plan 2007-2013: Transforming Ireland - A Better Quality of Life for All. Dublin: Government of Ireland. http://www2.ul.ie/pdf/932500843.pdf.

GoI. 2008. Building Ireland's Smart Economy: A Framework for Sustainable Economic Renewal, Executive Summary. Dublin: Government of Ireland. www.taoiseach.gov.ieleng/Building_Ireland's_Smart_Economy/Building_Ireland's_Smart_Ec onomy__Executive_Summary.pdf

GoI. 2012. Progress on the Implementation of the Government's Public Service Reform Plan. Dublin: Government of Ireland. http://per.gov.ie/wp-content/uploads/Statement-on-PublicService-Reform-Plan-6th-Sept-2012.pdf .

Gunder Frank, A. 1966. The development of underdevelopment. Monthly Review. 18, no.4.

Harpur, J. 2010. Innovation, Profit and the Common Good in Higher Education. The New Alchemy. London: Palgrave MacMillan.

Hazelkorn, E. 2013a. Higher Education's Future: A New Global Order? In Resilient universities, ed. R. Pritchard and J. E. Karlsen, 53-90. Oxford: Peter Lang Publishers. Forthcoming. 
Hazelkorn, E. 2013b. Has higher education lost control over quality? Chronicle of Higher Education, 23 May, http://chronicle.com/blogs/worldwise/has-higher-education-lost-controlover-quality/32321

Hazelkorn, E., Ryan, M., Gibson, A., and Ward, E. 2013. Recognising the Value of the Arts and Humanities in a Time of Austerity. HERAVALUE Ireland Report. EU HERA Programme. http://arrow.dit.ie/cgi/viewcontent.cgi?article=1042\&context=cserrep

HEA. 2009a. Terms of Reference, National Strategy for Higher Education in Ireland. Dublin: Higher Education Authority. http://www.hea.ie/en/node/1303.

HEA. 2009b. Policy Options for New Student Contributions in Higher Education, Report to Minister for Education and Science. Dublin: Higher Education Authority.

HEA. 2011. Sustainability Study. Aligning Participation, Quality and Funding in Irish Higher Education. Dublin: Higher Education Authority. http://www.hea.ie/files/files/file/News/SustainabilityReport.pdf.

HEA. 2012a. Higher Education Facts and Figures, 2011/2012. Dublin: Higher Education Authority. http://www.hea.ie/sites/default/files/hea_key_facts_figures_1112.pdf .

HEA. 2012b. Sustainability in Higher Education in Ireland - A Background Report. Dublin: Higher Education Authority. Unpublished.

HEA. 2012c. Towards a Future Higher Education Landscape. Dublin: Higher Education Authority. http://www.hea.ie/en/policy/national-strategy/implementation.

HEA. 2013a. A Proposed Strategy for Sustainability. Unpublished draft, May 7, 2013. Dublin: Higher Education Authority.

HEA. 2013b. Report to the Minister for Education and Skills on System Reconfiguration, Inter-Institutional Collaboration and System Governance in Irish Higher Education. Dublin: Higher Education Authority. http://www.hea.ie/sites/default/files/report_to_minister__system_configuration_2_0.pdf .

IMF. 2009. Country Report No. 09/195. Washington, D.C.: International Monetary Fund. http://www.imf.org/EXTERNAL/PUBS/FT/SCR/2009/CR09195.PDF.

Innovation Taskforce. 2010. Innovation Ireland. Report of the Innovation Taskforce. Dublin: Government of Ireland.

www.taoiseach.gov.ie/eng/Innovation_Taskforce/Report_of_the_Innovation_Taskforce.pdf

Kearns, M. 2009. Third level dismay at Greens' fees coup. The Sunday Business Post, October 18.

Lane, J. and Johnstone, B., ed. 2013. Higher Education Systems 3.0. Harnessing Systemness, Delivering Performance. New York: SUNY Press. Forthcoming.

Lynch, S. and Slattery, L. 2009. ESRI predicts no significant recovery in economy before 2011. The Irish Times, September 30.

http://www.irishtimes.com/newspaper/frontpage/2009/0930/1224255525566.html.

McConnell, D. 2009. State cannot afford seven universities, says UCC president. Sunday Independent, March 8.

McGuinness, S., Bergin, A., Kelly, E., McCoy, S., Smyth, E. and Timoney, K. 2012. A Study of Future Demand for Higher Education in Ireland. Pre-publication Version. Report to the Higher Education Authority. Dublin. https://share.hea.ie/Extranet/landscape-submissions/astudy-of-future-demand-for-higher-education-in-ireland/view 
NESC. 2009. Ireland's Five-Part Crisis: An Integrated National Response. Dublin: National Economic and Social Council.

Ó Riain, S. 2004. State, Competition and Industrial Change in Ireland 1991-1999. The Economic and Social Review, 35, no. 1, Spring.

O'Brien, C. 2008. Population of Ireland to reach $6.7 \mathrm{~m}$ by 2060. The Irish Times. August 27. http://www.irishtimes.com/newspaper/ireland/2008/0827/1219680032011.html.

Quinn, R. 2013. Correspondence from Minister of Education and Skills to Chairperson, Higher Education Authority, May 30. Dublin: Government of Ireland.

http://www.merrionstreet.ie/wp-content/uploads/2013/05/Letter.pdf

RTE News. 2007. Ireland's population growth rate fastest in EU, http://www.rte.ie/business/2007/1218/cso.html.

RTE. 2012. Quinn plans law change to force university compliance over pay. October 2. http://www.rte.ie/news/2012/1002/340040-university-pay-law/.

Skilbeck, M. 2003. Towards an integrated system of tertiary education - A discussion paper. Unpublished.

Swinbanks, D. 2013. Editorial. Nature Publishing Index 2012.

http://www.natureasia.com/en/publishing-index/pdf/NPI2012_Global.pdf\#page=26

von Prondzynski, F. 2009. Ireland is too small for a hierarchy of universities. The Irish Times, March 17.

Walsh, J. 2011. A Quiet Revolution: International Influence, Domestic Elites and the Transformation of Higher Technical Education in Ireland 1959-1972. Irish Educational Studies, 30, no. 3, 365-381.

\footnotetext{
${ }^{1}$ This refers to the European Union, European Central Bank and International Monetary Fund.

${ }^{2}$ GNP (gross national product) is considered a more accurate measurement in Ireland because it discounts the distortion effect of the multi-national sector which is included in GDP (gross domestic product) data. For most economies there is only a small difference between the two figures, but in Ireland GNP is about 20\% smaller than GDP. In 2011, the multinational sector accounted for about 1 in 7 jobs, equivalent to c.70\% exports, c. $80 \%$ of corporation tax and c.50\% of payroll taxes. Why this matters for calculations for government investment in higher education or research is because by using the smaller GNP base, investment can be shown as a greater percentage.

${ }^{3} \mathrm{NFQ}$ refers to the Irish National Framework of Qualifications. See http://www.nfq.ie/nfq/en/
} 